\title{
Effects of low-carbon economy on China's export trade
}

\author{
Dayong Wang
}

School of Economics and Management, Changchun University of Science and Technology,

Changchun, 130022, China

lovelywdy@163.com

\begin{abstract}
The development of low-carbon economy plays a major role on the optimization and upgrading of China's export trade, as well as the development of green trade and the improvement of the level of technology on the production of foreign products. However, in the short term it has some limitations, for instance, it reduces the competitive power of China's foreign trade and it hinders China from achieving its export potentials. It also deteriorates the trade environment as a whole. This article together with the reality of China responses regarding some measures about the development of China Foreign Trade is expected to show why and how important it is to ensure future energy efficiency improvements and a more advanced, low-carbon economy.
\end{abstract}

Keywords: low-carbon economy; foreign trade; trade competitive power.

\section{The optimization and upgrading of China's export trade}

Due to the crazy sweeping of the low-carbon economy all over the world and China exportoriented "high-energy-consuming and resource-dependent" products, China's improvement of economy, upgrading of industrial structure and enhancing international industrial position need to be achieved through export-oriented enterprises' actively developing new industry.

In order to change the "high-energy-consuming and resource-dependent" economic growth, reconciling the contradiction between the economic growth and protection of resources and the environment is essential. Moreover, to change the mode of growth of China fundamentally in ensuring that the economy achieves sustainable development, we ought to learn the development and application of new industrial technologies and low-carbon energy from developed countries. Thus, it is particularly worthwhile for us to learn the technological innovation in the field of traditional fossil energy source [1]. This must be done with the focus on positive impact of China's low-carbon industrial development. In this way, China can avoid repeating the high energy consumption patterns of production of Western countries in the past.

\section{Promoting the development of low-carbon products}

The widespread concept of low-carbon economy has forced the low-carbon industries. On one hand, the numbers of low-carbon products increase heavily because of barriers about low-carbon, which directly makes a substantial increase in the types of export products; On the other hand, the rise of the relevant industry has brought opportunities. If many export enterprises seize the opportunities, producing new types of low-carbon products based on updated technology, they can open a new market. This is a rare opportunity for China's enterprises to enter the world market. In addition, China is the world's second largest carbon resources country. And with more attention to low-carbon economy, carbon will be more circulated in the international arena as a commodity. Carbon trading will also become an important trading way [2]. More importantly, the prospects of China's domestic carbon trading market are quite broad. Thus, carbon trading will occupy a position in China's foreign trade to enrich the trading diversity.

\section{Conducive to the development of green trade and improvement of technological level}

Taking the green path of development of low-carbon economy, can better cope with the green barriers which are often encountered in foreign trade. This is expected to help promote the sustainable development of China's foreign trade. The development of low-carbon economy is a higher 
requirement, which need to consume a lot of resources to sustain the economic development. While China is still a developing country at the moment, it has failed to meet the requirements. However, because of this, through the development of low-carbon economy it will effectively stimulate many enterprises' scientific and technological innovation in China. This will improve the technological content of products and avoid payment of fines being levied on export carbon. Beside the replacement of outdated technologies with new technologies, the integration the traditional huge carbon emissions companies will help to optimize the export structure as well as to help enhance the technological level of China's foreign trade products.

\section{The adverse effects of low-carbon economy on China's export trade}

Carbon tariff barriers reducing the competitiveness of China's foreign trade

Carbon tariffs refer to sovereign states levy carbon dioxide emissions tariffs for the imported high energy-consuming products. These products are characterized by the presence of high carbon dioxide emission in the production process of the exporting country.

As a famous "world factory", China export mainly the processing trade and in most low-end and the products are high-carbon oriented. Under this low-carbon tide globalized, if the developed countries limit China's exports of carbon tariffs, China will face a variety of barriers in international trade, which is not conducive for smooth trade, resulting in China's foreign trade less competitive.

NTBs hinder China's exports

The most obvious non-tariff barrier in developed countries is by establishing certification standards for market access, which will exclude the substandard products from the market. Carbon labelling refers to marking the data of the merchandise's life cycle emissions of greenhouse gases in the form of labels so that consumers can understand the carbon product information. This helps in enhancing the consumers' low-carbon environmental awareness.

As China's export products are mostly high-carbon products. The introduction of carbon labelling will lead to the export enterprises investing enormous human and material capital to carbon standard certification in developed countries. This will increase production costs significantly. Thus, the commodity prices have to improved, which will result to the price advantage weaken and reducing the international competitiveness of export products. What is more is that, it will also reduce the foreign trade enterprises' profit margins and seriously affect the development of China's export industries [3].

Worsening trade environment

The developed countries have high level of economic development, advanced science and technology, gradually increased environmental requirements. In international trade these countries often want to import low-carbon products which will protect national ecological environment. In the background of low-carbon economy, these countries take measures to impose carbon tariffs to curb high-carbon imports, which require China to develop more low-carbon products instead of the original high-carbon product. Thus China need to make huge investments to bring in foreign advanced technology and equipment to develop low-carbon products. Carbon tariff barriers make the export products in developed countries gain great advantages compared to developing countries in technology, resulting in increased exports in developed countries and reduced exports in developing countries. Finally, developed countries charge higher prices for their products, making China to gain competitive advantage through its low-priced products to sustain its strategic position in international markets. Meanwhile if the price is too low it will face anti-dumping, so that China's foreign trade environment become worsen.

\section{Strategies of China's exports}

Adjusting the structure of export products and improving the competitiveness of low-carbon China's export enterprises should adjust the structure of export products, reducing or eliminating the past "high-energy-consuming and resource-dependent" orders, paying close attention to green trade measures in Western countries, increasing investment in product development and technology, 
actively establishing own brands and increasing export of high-tech products . In addition, as for the new Africa, ASEAN and Russia markets, the enterprises should consider the characteristics of these markets, producing targeted products in order to explore and consolidate those markets. All in all, by adjusting the structure of export products, improving the "low-carbon competitiveness" of China's export products, China's enterprises can have some development in the export transition. They would further respond better to the "carbon barriers."

The transformation of traditional high-carbon industry, low-carbon technological innovation

For traditional high-carbon industry, China should reform and help its development and transformation. For government, the government should give corresponding preferential policies in the technology, equipment and financing to encourage high-carbon industry initiative to upgrade; For businesses, companies need to be fully aware of the importance of energy saving and the companies should actively be involved in efforts towards the achievement of efficient and energy saving in production sites. Of course, the key to the transformation of high-carbon industry depends on breakthrough related technologies. As a result, businesses and/or government should increase investment in low-carbon technology innovation and encourage the development and application of low-carbon technologies as well as improve resource and energy efficiency.

Promoting industrial restructure and developing the service trade

In addition to the upgrade of the existing industries and enterprises, the structure of export industries needs to be adjusted in the export transition. Many industries are naturally low on resources and energy consumption. Modern service is a broader low-carbon industries, especially obvious in employment that can be accommodated, energy consumption and resource consumption compare to the traditional industry. In addition, China's service trade development space is very large. Developed countries such as countries in the EU and United States, trade in services account for more than 20\% for the proportion of foreign trade, while China still fluctuate around $10 \%$ for many years. This therefore shows that China's service trade has a bright prospect which is worthy to be the focus under the low-carbon economy background.

\section{Reference}

[1]. Gong Yunqiu, Chen Xiaoqing. The challenge analysis of china in foreign trade under the lowcarbon economy situation[J].China trade,2010(14)

[2].Huanghe, Zhao Renkang. Low-carbon economy and international trade rules remodeling [J]. Foreign Affairs Review, 2010(5)

[3].Wei Yuanjue.The way of China's processing trade under a low-carbon economy requires [J]. Chinese e-commerce, 2010 (5) 